\title{
胸郭出口症候群手術例の検討
}

——熊大式 TOS 臨床症状評価案を用いて——

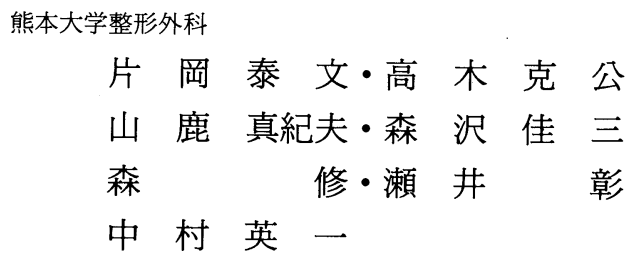

\section{Clinical Study of Operative Cases of Thoracic Outlet Syndrome using an Idea of Kumamoto University Thoracic Outlet Syndrome Evaluation Score}

by

\author{
Yasufumi Kataoka, Katsumasa Takagi, Makio Yamaga, \\ Keizo Morisawa, Osamu Mori, Akira Sei \\ and Eiichi nakamura
}

Department of Orthopaedic Surgery, Kumamoto University Medical School

Evaluation of thoracic outlet syndrome (TOS) is very difficult because of its various symptoms. We made an idia of Kumamoto University Thoracic Outlet Syndrome Evaluation Score which includes provisions of Pain, ADL disturbance, autonomic nerve symptom and examination findings. This time we evaluated the pre-and post-operative scores in 31 TOS patients . (41 sides, 18 male, and 23 female) In this study, we found the difference in postoperate score between male and female, Male patients had better results than female patient.

In conclusions, our TOS Evaluation Score is usefull, because it can clarify the symptoms of TOS by scoring.

\section{はじめに}

胸郭出口症候群 (以下 TOS と略す) は, 胸郭と肩甲 帯を連結する鎖骨と第一助骨の間や，その近傍の筋肉 などにより神経や血管が圧迫されて起こるとされてい る.しかし, 症状としては単に圧迫によるものだけで はなく, 二次的な神経炎症状, 心理的因子, 筋の緊張 性, 不良姿勢, 仕事内容および運動負荷などが複雑に 関与して, 上肢の疼痛・盘れ・急さ，肩～肩甲帯にか けての疼痛, こりなど多彩であり, さらに頭痛・不眠・ めまい・悪心嘔吐・食欲不振・倦怠感などの自律神経 障害と思われる不定愁訴を示す者も多い.
以上のごとく, TOS は症状が多岐に渡るため病態の 把握が難しく, 客観的な評価が困難な疾患であり, こ れまで脈管テストや主観的な判断のみで判定されてき た.

そこで, われわれはTOSに対して, 疼痛, ADL 障 害・自律神経症状·診察時所見を考慮した, 熊大式 TOS 臨床症状評価案を考案し用いてみたので報告する（表 $1)$.

\section{方法および対象}

疼痛の項目では, 上肢の肢位における痛みや盘れ感 を判定し, ADL 障害では上肢挙上時や負荷時, それに 
表 1 熊大式 Thoracic Outlet Syndrome 臨床症状評価案

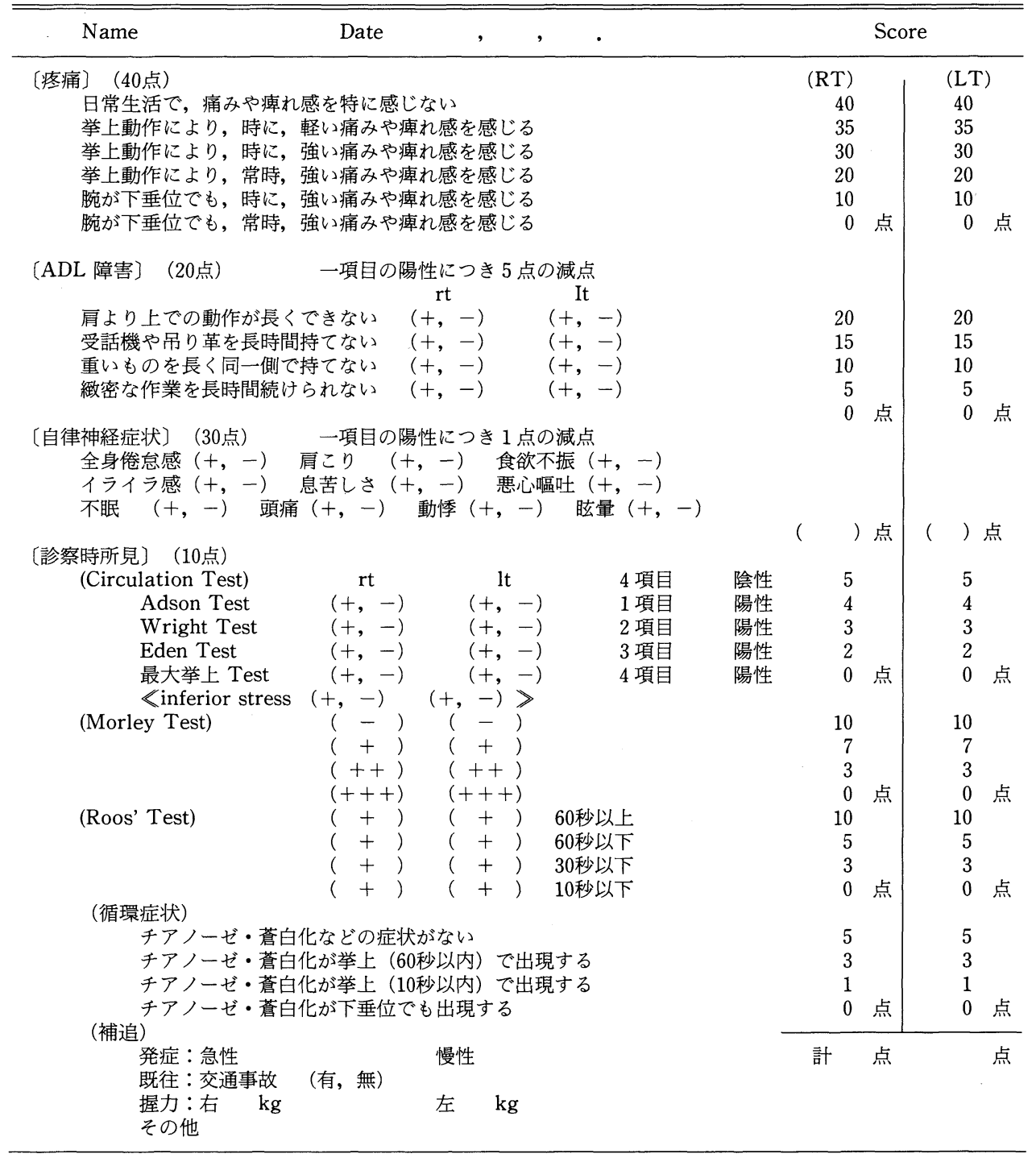

緻密な作業動作時の障害を判定している，また，これ まであまり評価の対象とされていなかった，自律神経 症状にも目を向け, 10 項目に付いてチェックを行った。 さらに R-R インターバルを測定して自律神経障害の 関与についても調べた

診察時所見は, Circulation test, Morley test, Roos' test およびその際の循環症状を総合したもので, Circulation testとしては, Adoson, Wright, Eden,最大挙上 の 4 項目と, 参考としての Inferior Stress test も行っ
ているが，これらの試験は正常人でも陽性率が高いた めに, 点数配分としては少なめに評価している.また, Roos'test に関しては, 3 分間ではかなりの人が陽性と なるため，1 分以上は正常範囲と判定した ${ }^{1)}$.

以上, 主要 4 項目の合計を 100 点として評価を行っ た.

今回, TOS の診断で, 第一肋骨切除を行った症例に おける術前・術後の経過をこの評価案を用いて検討し たので報告する。 
対象は手術を施行した TOS 症例, 31 名・41 側（男 子； 16 名 $\cdot 18$ 側，女； 15 名 $\cdot 23$ 側), 平均年令 28.3 才

(男子； 31.1 才，女； 24.8 才)であり, 評価は術前 1 週間および術後 $4.3 \pm 1.9$ 力月に行った。

\section{結果}

術前の $26.1 \pm 11.1$ 点（男；28.6士12.1点，女； $24.3 \pm 10.1$ 点）と比し, 術後は $72.2 \pm 20.0$ 点（男; $83.4 \pm 9.0$ 点, 女 $; 63.5 \pm 21.9$ 点) と改善を認めたが, 男性のほうが女性より良好な結果が得られた。また， 疼痛・ADL 障害・自律神経症状・診察時所見などのお のおのの項目についても検討してみた（表 2 ).

（図 1）は，4 項目および全体の Score を\%表示に して比較したものであるが, 男女合計の 41 症例におい ては, 全項目において手術前後に有意に改善を認めた。 また, 改善の程度としては, 疼痛・ADL 障害・診察時 所見・総合所見においては著明であったが, 自律神経 症状の項目は改善が相対的に少なかった。

しかし, 術前 R-R interval 測定により自律神経障害 の合併が確認されたグループでは, 術前の $3.4 \pm 2.0$ 点 から術後は $7.1 \pm 1.7$ 点と明らかに改善を認めた。 なおこの点については共同演者の山鹿らが報告してい る2).

男女別の\%比較では, 男性 18 例の場合は, 全般的に 手術後の改善が著明であり，手術前の自律神経障害の 程度が軽かった。（平均 $65 \%$ ，R-R interval 測定にて 異常は 2 名)

これに対して, 女性 23 例では, 手術前の自律神経障

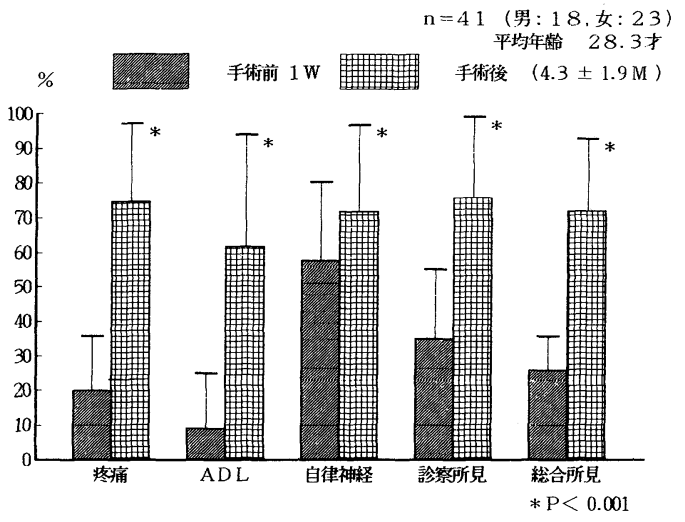

図 1 熊大式評価案を用いたT O S 手術例の術前・ 術後比較

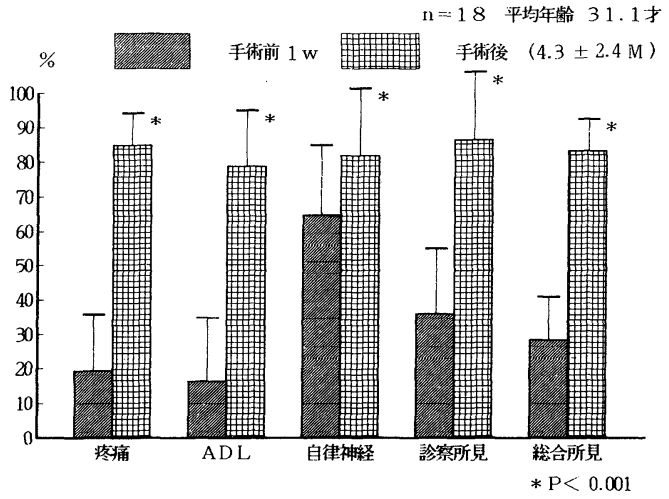

図 2 熊大式評価案を用いた男性 T O S 手術例の術 前・術後比較

果

\begin{tabular}{|c|c|c|c|c|c|c|c|c|}
\hline $\begin{array}{c}\text { Total Score } \\
\text { 術前 } \\
\text { 術後 }\end{array}$ & $\vdots$ & $\begin{array}{l}\text { (100点) } \\
26.1 \pm \\
72.2 \pm\end{array}$ & $\begin{array}{l}11.1 \text { 点 } \\
20.0 \text { 点 }\end{array}$ & $\begin{array}{l}\text { （男； } \\
\text { （男； }\end{array}$ & $\begin{array}{l}28.6 \pm \\
83.4 \pm\end{array}$ & $\begin{array}{r}12.1 \\
9.0\end{array}$ & $\begin{array}{l}\text { 女 } ; 24.3 \pm \\
\text { 女； } 63.5 \pm\end{array}$ & $\begin{array}{l}10.1) \\
21.9)\end{array}$ \\
\hline $\begin{array}{r}\text { 疼痛 } \\
\begin{array}{r}\text { 術前 } \\
\text { 術後 }\end{array}\end{array}$ & : & $\begin{array}{c}(40 \text { 点) } \\
8.0 \pm \\
29.9 \pm\end{array}$ & $\begin{array}{l}6.7 \text { 点 } \\
9.0 \text { 点 }\end{array}$ & $\begin{array}{l}\text { （男； } \\
\text { （男； }\end{array}$ & $\begin{array}{r}7.8 \pm \\
33.9 \pm\end{array}$ & $\begin{array}{l}7.1 \\
3.6\end{array}$ & $\begin{array}{l}\text { 女： } 8.3 \pm \\
\text { 女： } 26.7 \pm\end{array}$ & $\begin{array}{r}6.4) \\
10.6)\end{array}$ \\
\hline $\begin{array}{c}\text { ADL 障害 } \\
\text { 術前 } \\
\text { 術後 }\end{array}$ & $\vdots$ & $\begin{array}{c}\text { ( 20点) } \\
1.8 \pm \\
12.4 \pm\end{array}$ & $\begin{array}{l}3.1 \text { 点 } \\
6.2 \text { 点 }\end{array}$ & $\begin{array}{l}\text { （男； } \\
\text { （男； }\end{array}$ & $\begin{array}{r}3.3 \pm \\
15.8 \pm\end{array}$ & $\begin{array}{l}3.7 \\
3.4\end{array}$ & $\begin{array}{ll}\text { 女: } & 0.7 \pm \\
\text { 女: } & 9.8 \pm\end{array}$ & $\begin{array}{l}1.7) \\
6.5)\end{array}$ \\
\hline $\begin{array}{c}\text { 自律神経症状 } \\
\text { 術前 } \\
\text { 術後 }\end{array}$ & $\vdots$ & $\begin{array}{l}\text { ( } 10 \text { 点) } \\
5.8 \pm \\
7.2 \pm\end{array}$ & $\begin{array}{l}2.2 \text { 点 } \\
2.5 \text { 点 }\end{array}$ & $\begin{array}{l}\text { （男； } \\
\text { （男； }\end{array}$ & $\begin{array}{l}6.5 \pm \\
8.2 \pm\end{array}$ & $\begin{array}{l}2.0 \\
2.0\end{array}$ & $\begin{array}{ll}\text { 女: } & 5.3 \pm \\
\text { 女：} & 6.4 \pm\end{array}$ & $\begin{array}{l}2.2) \\
2.5)\end{array}$ \\
\hline $\begin{array}{r}\text { 診察時所見 } \\
\text { 術前 } \\
\text { 術後 }\end{array}$ & $\vdots$ & $\begin{array}{l}\text { ( } 30 \text { 点) } \\
10.6 \pm \\
22.8 \pm\end{array}$ & $\begin{array}{l}6.0 \text { 点 } \\
6.9 \text { 点 }\end{array}$ & $\begin{array}{l}\text { ( 男 } ; \\
\text { ( 男 }\end{array}$ & $\begin{array}{l}10.9 \pm \\
26.0 \pm\end{array}$ & $\begin{array}{l}5.8, \\
4.7\end{array}$ & $\begin{array}{l}\text { 女：10.3 } \\
\text { 女： } 20.3 \pm\end{array}$ & $\begin{array}{l}6.1) \\
7.2)\end{array}$ \\
\hline
\end{tabular}




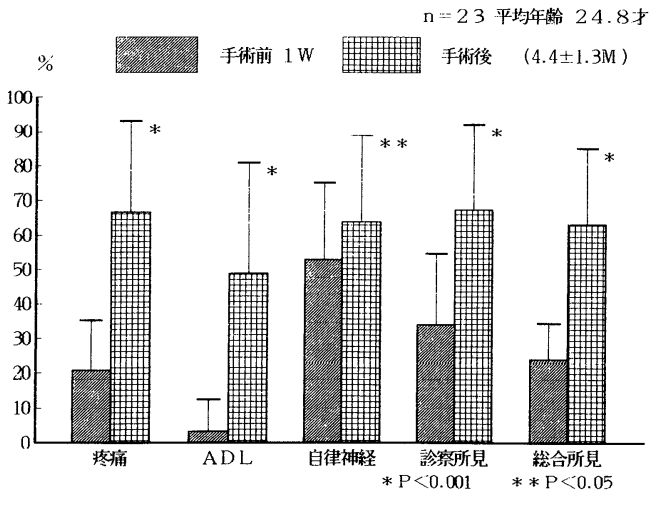

図 3 熊大式評価案を用いた女性 T O S 手術例の術 前・術後比較

害の程度が，男性より強い傾向にあった（平均 $53 \%$, R-R interval 測定にて異常は 6 名)，さらに ADL 障害 の程度が男性の（16.5土18.5\%）に比べて女性では

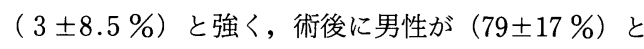
改善するのに対して女性では $(49 \pm 32.5 \%)$ であった. また, 術後の全体的な改善も男性に比べて女性では術 後 Score 63.5 21.9 点と低めであり, 改善の程度に症 例間のバラツキが多く認められた（図 2.3 ).

\section{考察}

41 例の TOS 手術症例について熊大式チャートを用い て検討してみた，手術前のスコアーでは男性，女性と もほぼ同じスコアーであったが，第一助骨切除術を行 った後では, 男性：83.4土9 点と良好な結果が得られ たのに対して，女性は：63.5 21.9 点と男性例に比へ 改善程度が低かった，とくに，疼痛の項目では術後に 痛みは改善するが, 盘れ感が残存する例が女性に多か った.

この男性と女性の術後成績における予想以上の差が 認められたことは, 男女間の解剖学的相違によるもの や，筋の緊張性・関節の Laxity・職業それと自律神経 障害などの影響によるものと推測されたが, 今回の検 討では成績不良例に対する検討は行っておらず，今後 の検討が必要であると思われた。

今回,われわれは TOSの主要症状・所見から, 疼痛・ ADL 障害・自律神経症状および診察時所見の大項目を 細分化して, 客観的な評価法を考案し使用した。そし て，この評価法に対してはさらに今後の検討を要する と思われるが，これまで脈管テストや主観的な判断の
みで判定されてきた, TOS 症状のあいまいさを点数化 することにより, 明確なものとすることができ, 実際 に使用してみて臨床症状とも良く対応し非常に有用で あった。

このような客観的評価法を用いることにより，TOS の臨床症状および病態の把握がより確実に成し得るも のと考えられる.

\section{ま と め}

1. TOS の診断で第一肋骨切除を行った症例におけ る術前・術後の経過を熊大式 TOS 臨床症状評価案を用 いて検討した.

2. 臨床症状評価案での点数化により TOS 症状を かなり明確なものとすることができ非常に有用であっ た.

3. 男性と女性の術後成績において予想以上の差が 認められたが，この点については今後検討を加えてい きたい.

\section{参 考 文 献}

1）高岸直人：胸郭出口症候群における諸検査の陽性率 の統計的考察－正常群と患者群の陽性率の比較検討一. 整形外科と災害外科, $30448-451,1982$.

2）山鹿真紀夫：胸郭出口症候郡における自律神経障害 の検討一心電図 $\mathrm{R}-\mathrm{R}$ 間隔変動を用いた自律神経機能検 查法に関して一肩関節, $12: 129-133,1988$.

\section{質 問福岡大学 高岸 直人}

術後に新たに出現した疼痛などは評価表に反映され てますか。

\section{解 答熊本大学 片岡 泰文}

本評価案は TOS の全体像を客観的に把握するために 考案した. 術前後の変化は, ある程度は反映されてい ると思うが, 細部に関しては評価できていない.

\section{質 問長崎大学 伊藤 信之} 術後に好結果を期待できる項目は何ですか.

\section{解 答 熊本大学 片岡 泰文}

今回の評価案の検討からは男性は女性よりも良かっ た. Loose Shoulder や Droopy shoulder Syndrome などの要素の有るものは慎重に検討する必要が有る. 